\title{
Therapeutic Monitoring of Class I Antiarrhythmic Agents Using High-Resolution Electrocardiography Instead of Blood Samples
}

\author{
Igor Sutovsky, MD; Takao Katoh, MD; Hideo Takayama, MD; \\ Tadaaki Ono, MD; Teruo Takano, MD
}

\begin{abstract}
Antiarrhythmic therapy requires monitoring of serum drug concentrations to determine a patient's optimal oral dose of medication. Repeated examination of blood samples, however, is costly and time-consuming, so the present study evaluated whether changes in serum concentrations could be estimated from changes in electrocardiographic (ECG) parameters. Of 36 patients receiving antiarrhythmic drugs for supraventricular or ventricular arrhythmias, 12 were treated with flecainide, 12 with pilsicainide, and 12 with pirmenol. Signal-averaged ECG (SAECG) were recorded before starting drug administration, 1 month later, and twice during ongoing therapy. At the time of the 2nd to the 4th recordings, serum concentrations of the drugs were also measured. As previously reported, all agents, but especially flecainide and pilsicainide, prolonged the filtered QRS (f-QRS) and the duration of low-amplitude signals at the terminal portion of the QRS complex. The SAECG parameters varied between the recordings made during therapy. Differences in the duration of the f-QRS between 2 recordings correlated significantly with differences in serum drug concentrations $(r=0.91$ for flecainide, $r=0.70$ for pilsicainide, and $\mathrm{r}=0.61$ for pirmenol). No significant correlation between drug concentration and other SAECG parameters was found. Changes in the serum concentration of flecainide, pilsicainide and pirmenol can be estimated from changes in the duration of the f-QRS on the SAECG and periodic monitoring of such could help reduce the number of repeat measurements of drug concentrations in blood samples. (Circ J 2003; 67: 195-198)
\end{abstract}

Key Words: Flecainide; High-resolution electrocardiography; Pilsicainide; Pirmenol

A patient's optimal dose of oral medication for longterm antiarrhythmic treatment must be determined by therapeutic monitoring, usually frequent measurements of serum drug concentration; however, such measurements are costly and time-consuming. In previous studies, clinical administration of antiarrhythmic agents was found to cause changes in signal-averaged electrocardiographic (SAECG) parameters ${ }^{1}$ and each antiarrhythmic agent affected the electrocardiographic (ECG) variables in a different manner.,3 Also, it has been reported that SAECG is more sensitive than a standard ECG in detecting the changes in QRS duration resulting from administration of class I antiarrhythmic drugs.,11 Therefore, the purposes of the present study were to compare the ECG changes caused by administration of 3 class I antiarrhythmic agents (flecainide, pilsicainide and, pirmenol), and to identify the SAECG parameters that might be used to estimate changes in serum concentration of antiarrhythmic agents during monitoring for long-term therapy.

\section{Methods}

\section{Patients}

We enrolled 36 patients (12 taking flecainide; 12 pilsi-

(Received July 30, 2002; revised manuscript received October 28, 2002; accepted November 26, 2002)

First Department of Internal Medicine, Nippon Medical School, Tokyo, Japan

Mailing address: Takao Katoh, MD \& Igor Sutovsky, MD, First Department of Internal Medicine, Nippon Medical School, 1-1-5 Sendagi, Bunkyo-ku, Tokyo 113-8603, Japan cainide; 12 , pirmenol) who had symptomatic ventricular or supraventricular arrhythmias. The underlying heart diseases included coronary artery disease (CAD), hypertensive heart disease, cardiomyopathy and valvular disease, but in some cases there was no underlying heart disease (Table 1). Of those with CAD, none had unstable angina. Three patients had a history of old myocardial infarction, but their cardiac function were not suppressed. No significant difference was seen in the distribution of diagnoses among the groups treated with each of the 3 drugs. Mean age was $63 \pm 17$ years. Patients with bundle branch block or other conduction disturbances were excluded.

Informed consent was obtained from the patients.

\section{Measurement of SAECG Parameters}

We used a NEC-DP 1100 signal processor for recording and measuring 3 conventional SAECG parameters: (1) the duration of the total filtered QRS (f-QRS); (2) the duration of the low-amplitude $(<40 \mu \mathrm{V})$ signal at the terminal portion of the QRS complex (LAS40); and (3) the root mean square voltage of the last $40 \mathrm{~ms}$ of the QRS complex (RMS40). The SAECG was recorded in the resting state, and the heart rate during recordings remained within the range of 60-90 beats $/ \mathrm{min}$ in all patients.

The initial SAECG recording was made before beginning antiarrhythmic therapy, followed by a second recording at 1 month after initiation of drug administration to ensure steady-state conditions. Patients were treated with standard recommended therapeutic doses of each antiarrhythmic drug, but these were sometimes modified according to the age and weight of the patient, as well as by the 
Table 1 Underlying Heart Diseases

\begin{tabular}{lcccc}
\hline \hline & Flecainide & Pilsicainide & Pirmenol & Total \\
\hline No. of patients & 12 & 12 & 12 & 36 \\
Average age (years) & $64 \pm 13$ & $59 \pm 11$ & $67 \pm 17$ & $63 \pm 17$ \\
M/F & $7 / 5$ & $8 / 4$ & $6 / 6$ & $21 / 15$ \\
Underlying disease & & 1 & 3 & 7 \\
$\quad$ Coronary artery disease & 3 & 1 & 2 & 3 \\
(old myocardial infarction) & 0 & 4 & 2 & 9 \\
Valvular disease & 3 & 1 & 0 & 1 \\
$\quad$ Cardiomyopathy & 0 & 6 & 7 & 19 \\
None & 6 & & & \\
\hline
\end{tabular}

Table 2 Effect of Flecainide on SAECG Parameters

\begin{tabular}{|c|c|c|c|c|c|c|c|c|c|c|c|c|}
\hline \multirow[b]{2}{*}{$\begin{array}{l}\text { Patient } \\
\text { no. }\end{array}$} & \multicolumn{2}{|c|}{$f-Q R S$} & \multirow{2}{*}{$\begin{array}{c}\Delta \\
f Q R S \\
(m s)\end{array}$} & \multicolumn{2}{|c|}{$R M S 40$} & \multirow{2}{*}{$\begin{array}{c}\Delta \\
R M S 40 \\
(\mu V)\end{array}$} & \multicolumn{2}{|c|}{ LAS40 } & \multirow{2}{*}{$\begin{array}{c}\Delta \\
\text { LAS40 } \\
(m s)\end{array}$} & \multicolumn{2}{|c|}{ Conc. } & \multirow{2}{*}{$\begin{array}{c}\Delta \\
\text { conc. } \\
(n g / m l)\end{array}$} \\
\hline & $\begin{array}{l}\text { no.1 } \\
(m s)\end{array}$ & $\begin{array}{l}\text { no.2 } \\
(\mathrm{ms})\end{array}$ & & $\begin{array}{l}n o .1 \\
(\mu \mathrm{V})\end{array}$ & $\begin{array}{l}n o .2 \\
(\mu V)\end{array}$ & & $\begin{array}{l}\text { no.1 } \\
\text { ( } \mathrm{ms} \text { ) }\end{array}$ & $\begin{array}{l}\text { no.2 } \\
(\mathrm{ms})\end{array}$ & & $\begin{array}{c}\text { no.l } \\
(\mathrm{ng} / \mathrm{ml})\end{array}$ & $\begin{array}{c}n o .2 \\
(\mathrm{ng} / \mathrm{ml})\end{array}$ & \\
\hline 1 & 116 & 125 & 9 & 5.4 & 2.6 & -2.8 & 72 & 83 & 11 & 141 & 188 & 47 \\
\hline 2 & 113 & 122 & 9 & 4.1 & 2.9 & -1.2 & 51 & 61 & 10 & 325 & 431 & 106 \\
\hline 3 & 98 & 106 & 8 & 11.3 & 8.4 & -2.9 & 36 & 48 & 12 & 148 & 248 & 100 \\
\hline 4 & 117 & 125 & 8 & 2.7 & 1.7 & -1 & 72 & 81 & 9 & 194 & 261 & 67 \\
\hline 5 & 111 & 114 & 3 & 3.3 & 5 & 1.7 & 53 & 59 & 6 & 105 & 127 & 22 \\
\hline 6 & 108 & 130 & 22 & 4 & 3 & -1 & 0 & 0 & 0 & 281 & 600 & 319 \\
\hline 7 & 98 & 109 & 11 & 11.7 & 5.5 & -6.2 & 46 & 43 & -3 & 170 & 233 & 63 \\
\hline 8 & 106 & 111 & 5 & 5.3 & 4.4 & -0.9 & 61 & 71 & 10 & 257 & 328 & 71 \\
\hline 9 & 120 & 121 & 1 & 3.5 & 3.4 & -0.1 & 63 & 62 & -1 & 267 & 283 & 16 \\
\hline 10 & 121 & 126 & 5 & 3.2 & 3.4 & 0.2 & 52 & 58 & 6 & 376 & 401 & 25 \\
\hline 11 & 104 & 106 & 2 & 5 & 4.3 & -0.7 & 52 & 58 & 6 & 190 & 204 & 14 \\
\hline 12 & 99 & 110 & 11 & 12 & 6.5 & -5.5 & 46 & 55 & 9 & 192 & 270 & 78 \\
\hline \multirow[t]{2}{*}{ Mean } & 109.3 & 117.1 & 7.8 & 5 & 4.3 & -1.7 & 50.3 & 56.6 & 6.3 & 220.5 & 297.8 & 77.3 \\
\hline & & & $p<0.001$ & & & $p=0.026$ & & & $p=0.001$ & & & $p<0.01$ \\
\hline
\end{tabular}

SAECG, signal-averaged ECG.

Table 3 Effect of Pilsicainide on SAECG Parameters

\begin{tabular}{|c|c|c|c|c|c|c|c|c|c|c|c|c|}
\hline \multirow[b]{2}{*}{$\begin{array}{l}\text { Patient } \\
\text { no. }\end{array}$} & \multicolumn{2}{|c|}{$f-Q R S$} & \multirow{2}{*}{$\begin{array}{c}\Delta \\
f Q R S \\
(m s)\end{array}$} & \multicolumn{2}{|c|}{ RMS40 } & \multirow{2}{*}{$\begin{array}{c}\Delta \\
R M S 40 \\
(\mu V)\end{array}$} & \multicolumn{2}{|c|}{ LAS40 } & \multirow{2}{*}{$\begin{array}{c}\Delta \\
L A S 40 \\
(m s)\end{array}$} & \multicolumn{2}{|c|}{ Conc. } & \multirow{2}{*}{$\begin{array}{c}\Delta \\
\text { conc. } \\
(n g / m l)\end{array}$} \\
\hline & $\begin{array}{l}\text { no.1 } \\
(m s)\end{array}$ & $\begin{array}{l}\text { no.2 } \\
\text { (ms) }\end{array}$ & & $\begin{array}{l}\text { no.1 } \\
(\mu \mathrm{V})\end{array}$ & $\begin{array}{l}n o .2 \\
(\mu V)\end{array}$ & & $\begin{array}{l}\text { no.1 } \\
\text { (ms) }\end{array}$ & $\begin{array}{l}\text { no.2 } \\
\text { ( } m s)\end{array}$ & & $\begin{array}{c}n o .1 \\
(\mathrm{ng} / \mathrm{ml})\end{array}$ & $\begin{array}{c}n o .2 \\
(\mathrm{ng} / \mathrm{ml})\end{array}$ & \\
\hline 1 & 118 & 123 & 5 & 8.8 & 8.2 & -0.6 & 33 & 52 & 19 & 643 & 786 & 143 \\
\hline 2 & 90 & 100 & 10 & 7.2 & 6.8 & -0.4 & 68 & 79 & 11 & 621 & 951 & 330 \\
\hline 3 & 105 & 110 & 5 & 9.8 & 8.5 & -1.3 & 52 & 36 & -16 & 451 & 637 & 186 \\
\hline 4 & 109 & 111 & 2 & 3.1 & 3.7 & 0.6 & 61 & 81 & 20 & 402 & 484 & 82 \\
\hline 5 & 124 & 127 & 3 & 9.4 & 9.1 & -0.3 & 44 & 53 & 9 & 480 & 564 & 84 \\
\hline 6 & 113 & 119 & 6 & 5.3 & 7.3 & 2 & 0 & 0 & 0 & 476 & 640 & 164 \\
\hline 7 & 106 & 110 & 4 & 2.5 & 2.1 & -0.4 & 25 & 46 & 21 & 399 & 486 & 87 \\
\hline 8 & 117 & 122 & 5 & 6 & 3.1 & -2.9 & 46 & 69 & 23 & 423 & 550 & 127 \\
\hline 9 & 113 & 121 & 8 & 12.9 & 14 & 1.1 & 34 & 68 & 34 & 561 & 616 & 55 \\
\hline 10 & 116 & 127 & 11 & 7.2 & 5.9 & -1.3 & 52 & 44 & -8 & 469 & 641 & 172 \\
\hline 11 & 95 & 107 & 12 & 4.7 & 3.7 & -1 & 58 & 66 & 8 & 503 & 774 & 271 \\
\hline 12 & 115 & 119 & 4 & 13.2 & 14.1 & 0.9 & 42 & 46 & 4 & 549 & 583 & 34 \\
\hline Mean & 110.1 & 116.4 & $\begin{array}{c}6.3 \\
p<0.001\end{array}$ & 7.5 & 7.2 & $\begin{array}{c}-0.3 \\
p=N S\end{array}$ & 42.9 & 53.3 & $\begin{array}{c}10.4 \\
p=0.027\end{array}$ & 498 & 643 & $\begin{array}{c}145 \\
p<0.001\end{array}$ \\
\hline
\end{tabular}

severity of arrhythmias. At the time of the second recording, serum drug concentrations had been determined.

Two subsequent SAECG recordings were accompanied by blood sampling to determine the changes in the serum concentrations of the drugs. The time interval after the second SAECG recording at which these later paired examinations were carried out ranged from 2 to 4 months.

The patients were followed up at our outpatient clinic and the blood samples were usually taken within $2-4 \mathrm{~h}$ of drug administration.
Statistical Analysis

Data are given as mean \pm SD. Paired two-tailed Student's $\mathrm{t}$-Tests were used to compare continuous variables. $\mathrm{P}$ values less than 0.05 were considered to indicate significance.

\section{Results}

Effects of the Drugs on SAECG Parameters

$f$-QRS Flecainide, pilsicainide and pirmenol all prolonged the f-QRS significantly (Tables 2-4).

LAS40 All 3 drugs significantly prolonged LAS40, but 
Table 4 Effect of Pirmenol on SAECG Parameters

\begin{tabular}{|c|c|c|c|c|c|c|c|c|c|c|c|c|}
\hline \multirow[b]{2}{*}{$\begin{array}{l}\text { Patient } \\
\text { no. }\end{array}$} & \multicolumn{2}{|c|}{$f-Q R S$} & \multirow{2}{*}{$\begin{array}{c}\Delta \\
f Q R S \\
(m s)\end{array}$} & \multicolumn{2}{|c|}{$R M S 40$} & \multirow{2}{*}{$\begin{array}{c}\Delta \\
R M S 40 \\
(\mu V)\end{array}$} & \multicolumn{2}{|c|}{$L A S 40$} & \multirow{2}{*}{$\begin{array}{c}\Delta \\
\stackrel{\Delta}{(m s)}\end{array}$} & \multicolumn{2}{|c|}{ Conc. } & \multirow{2}{*}{$\begin{array}{c}\Delta \\
\text { conc. } \\
(n g / m l)\end{array}$} \\
\hline & $\begin{array}{l}n o .1 \\
\text { (ms) }\end{array}$ & $\begin{array}{l}\text { no.2 } \\
\text { (ms) }\end{array}$ & & $\begin{array}{l}n o .1 \\
(\mu V)\end{array}$ & $\begin{array}{l}n o .2 \\
(\mu V)\end{array}$ & & $\begin{array}{l}n \text { no.1 } \\
(\mathrm{ms})\end{array}$ & $\begin{array}{l}n o .2 \\
(\mathrm{~ms})\end{array}$ & & $\begin{array}{c}n o .1 \\
(\mathrm{ng} / \mathrm{ml})\end{array}$ & $\begin{array}{c}n o .2 \\
(\mathrm{ng} / \mathrm{ml})\end{array}$ & \\
\hline 1 & 120 & 124 & 4 & 10.7 & 6.7 & -4 & 22 & 50 & 28 & 721 & 1079 & 358 \\
\hline 2 & 141 & 148 & 7 & 5.7 & 4.8 & -0.9 & 131 & 137 & 6 & 744 & 1672 & 928 \\
\hline 3 & 100 & 103 & 3 & 7.6 & 6 & -1.6 & 50 & 82 & 32 & 440 & 942 & 502 \\
\hline 4 & 110 & 111 & 1 & 2.9 & 3.5 & 0.6 & 60 & 59 & -1 & 769 & 785 & 16 \\
\hline 5 & 114 & 116 & 2 & 5.4 & 4.8 & -0.6 & 43 & 62 & 19 & 372 & 501 & 129 \\
\hline 6 & 112 & 117 & 5 & 2.6 & 1.2 & -1.4 & 0 & 0 & 0 & 980 & 1221 & 241 \\
\hline 7 & 93 & 96 & 3 & 14.8 & 11.9 & -2.9 & 28 & 33 & 5 & 580 & 684 & 104 \\
\hline 8 & 102 & 106 & 4 & 6 & 3.3 & -2.7 & 0 & 0 & 0 & 1097 & 1355 & 258 \\
\hline 9 & 89 & 96 & 7 & 9.2 & 5 & -4.2 & 45 & 42 & -3 & 689 & 1198 & 509 \\
\hline 10 & 106 & 115 & 9 & 4.8 & 3.5 & -1.3 & 0 & 0 & 0 & 549 & 602 & 53 \\
\hline 11 & 116 & 128 & 14 & 4.7 & 1.7 & -3 & 57 & 65 & 8 & 519 & 1308 & 789 \\
\hline 12 & 111 & 112 & 1 & 2.5 & 2.9 & 0.4 & 43 & 59 & 16 & 370 & 434 & 64 \\
\hline \multirow[t]{2}{*}{ Mean } & 109.4 & 114.3 & 4.9 & 6.4 & 4.6 & -1.8 & 39.9 & 49.1 & 9.2 & 653 & 982 & 329 \\
\hline & & & $p<0.001$ & & & $p=0.002$ & & & $p=0.022$ & & & $p<0.003$ \\
\hline
\end{tabular}

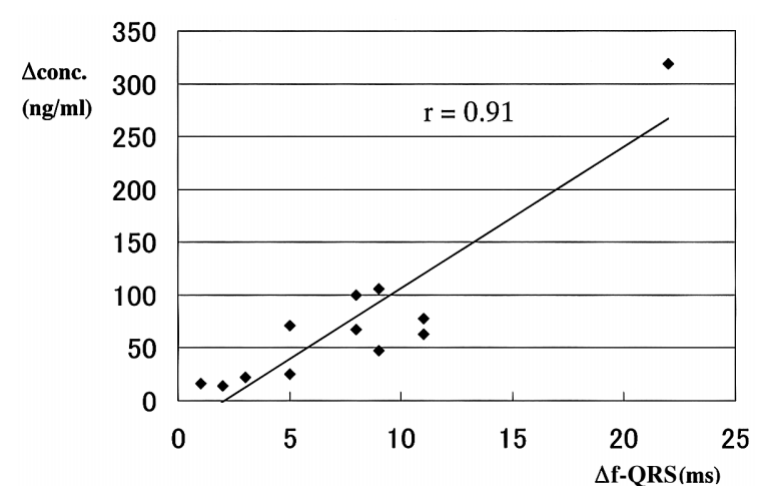

Fig 1. Correlations between $\Delta \mathrm{f}-\mathrm{QRS}$ and flecainide $\Delta$ serum concentration.

particularly pilsicainide (Tables 2-4).

RMS40 RMS40 was decreased equally by flecainide and pirmenol, and pilsicainide had a minimal effect only (Tables 2-4).

Mean serum concentrations at 1 month after beginning therapy were $218 \mathrm{ng} / \mathrm{ml}$ for flecainide, $480 \mathrm{ng} / \mathrm{ml}$ for pilsicainide, and $514 \mathrm{ng} / \mathrm{ml}$ for pirmenol; these concentrations were within the therapeutic range in all patients.

\section{Changes in Serum Drug Concentration and the SAECG Parameters}

Serum concentrations of flecainide correlated strongly with change in $\mathrm{f}-\mathrm{QRS}(\mathrm{r}=0.91$; Fig 1$)$ as did those of pilsicainide ( $\mathrm{r}=0.70$; Fig 2$)$ and pirmenol $(\mathrm{r}=0.61$; Fig 3$)$. The other 2 SAECG parameters $(\triangle \mathrm{RMS} 40$ and $\triangle$ LAS40) did not show a significant correlation with the serum concentration of any of the 3 antiarrhythmic agents.

\section{Discussion}

Monitoring of the serum concentration of antiarrhythmic agents by repeated blood samples is costly, and unpleasant for patients. In the present study, with flecainide in particular, we observed a significant correlation between serum drug concentration and changes in the $\mathrm{f}-\mathrm{QRS}$ on SAECG.

In clinical practice, prolongation or shortening of the $\mathrm{f}$ QRS can be taken to suggest excessively high or low concentrations of flecainide, and to indicate the need for a

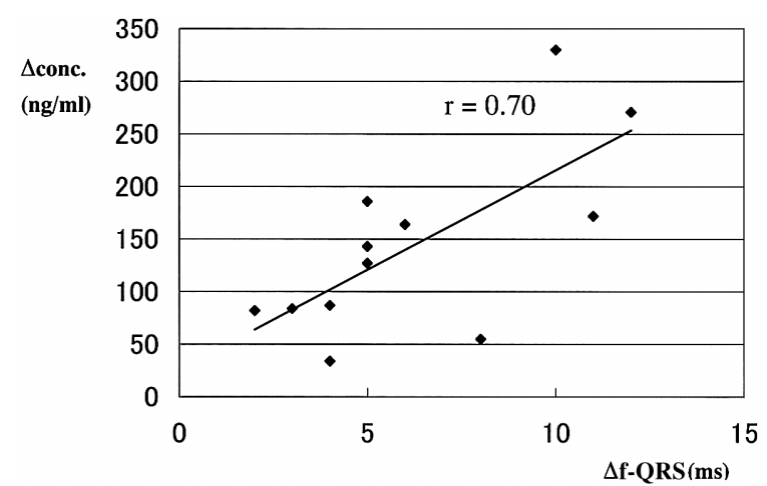

Fig 2. Correlations between $\Delta \mathrm{f}-\mathrm{QRS}$ and pilsicainide $\Delta$ serum concentration.

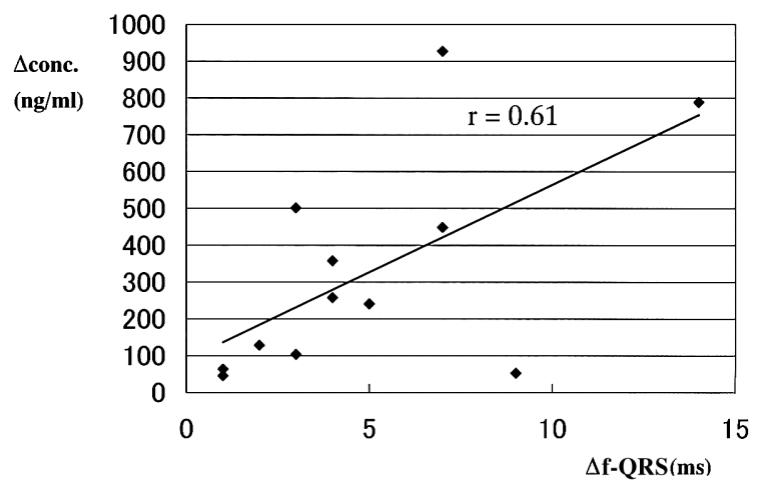

Fig 3. Correlations between $\Delta \mathrm{f}-\mathrm{QRS}$ and pirmenol $\Delta$ serum concentration.

blood sample to determine the serum drug concentration. On the other hand, if the $\mathrm{f}-\mathrm{QRS}$ is stable, frequent serum determinations probably are unnecessary.

The mechanism of prolongation of the $\mathrm{f}-\mathrm{QRS}$ by class I antiarrhythmic drugs is thought to be a potent blockade of the sodium channels that slows phase 0 depolarization and intraventricular conduction? The rate at which these drugs bind to or dissociate from the sodium channels is sufficiently slow for a strong blocking action to be exerted, even during sinus rhythm. However, the kinetics of each of these 
drugs (and especially the affinity for the $\mathrm{Na}^{+}$channel) differ. Flecainide 6 and pilsicainide exhibit very slow kinetics, whereas pirmenol has different features, including a shorter time constant, ${ }^{1}$ which indicates that presumption of the serum concentration of pirmenol during sinus rhythm will be more difficult than with the other 2 drugs. Furthermore, our study results imply that of the 3 class I antiarrhythmic agents we studied, flecainide has the most stable concentration, which is surprising considering that it has been found to have nonlinear kinetics even in patients with normal kidney and liver function? Therefore, even in patients with normal renal function, and without heart failure, chronic administration of the drug may lead to its unexpected accumulation, probably because of genetically poor metabolism, so monitoring the plasma concentration is necessary?

Most of the class Ia and class Ic antiarrhythmic drugs are excreted mainly by the kidney and therefore their use in patients with impaired renal function must be carefully monitored by clinicians?

The main limitation of the present study is that SAECG parameters can be affected by many factors not associated with antiarrhythmic therapy, such as transient ischemia, changes in autonomic tone, and conduction disturbances?,10 However, we conclude that changes in the serum concentration of flecainide, pilsicainide and pirmenol can be estimated from changes in the duration of $\mathrm{f}-\mathrm{QRS}$, which is prolonged in a dose-dependent manner, during SAECG recording. Such a screening test could improve the therapeutic monitoring of these antiarrhythmic agents by reducing the frequency of serum drug assays.

\section{References}

1. Kodama I, Ogawa S, Inoue H, Kasanuki H, Kato T, Mitamura H, et al. Profile of aprindine, cibenzoline, pilsicainide and pirmenol in the framework of the Sicilian Gambit. Jpn Circ J 1999; 63: 1-12.

2. Lee JH, Rosen MR. Electrophysiologic effects of pirmenol, its metabolite 2, and enatiomers, on cardiac Purkinje fibers. $J$ Cardiovasc Pharmacol 1993; 22: 416-422.

3. Pentel PR, Fifield J, Salerno DM. Lack of effect of hypertonic sodium bicarbonate on QRS duration in patients taking therapeutic doses of class Ic antiarrhythmic drugs. J Clin Pharmacol 1990; 30: 789-794.

4. Dennis AR, Ross DL, Richards DA, Cody DV, Russel PA, Young AA, et al. Effect of antiarrhythmic therapy on delayed potentials detected by the signal-averaged electrocardiogram in patients with ventricular tachycardia after acute myocardial infarction. Am J Cardiol 1986; 58: $261-265$.

5. Shirayama T, Inoue D, Inoue M, Tasumi T, Yamahara Y, Asayama J, et al. Electrophysiological effects of sodium channel blockers on guinea pig left atrium. J Pharmacol Exp Ther 1991; 259: 884-893.

6. Watanabe H, Watanabe I, Nakai T, Oshikawa N, Kunimoto S, Masaki R, et al. Frequency-dependent electrophysiological effects of flecainide, nifekalant and d, 1-sotalol on the human atrium. Jpn Circ J 2001; 65: 1-6.

7. Boriani G, Strocchi E, Capucci A, Calliva R, Frabetti L, Ambrosioni E, et al. Flecainide: Evidence of non-linear kinetics. Eur J Clin Pharmacol 1991; 41: 57-59.

8. Honda T, Soejima H, Honda T. Long-term low-dose cibenzoline in patients with chronic renal failure undergoing hemodialysis. Jpn Circ J 2000; 64: 72-75.

9. Engel TR, Pierce DL, Patil KD. Reproducibility of the signal-averaged electrocardiogram. Am Heart J 1991; 122: $1652-1660$.

10. Raineri AA, Traina M, Lombardo RM, Rotolo A. Relation between late potentials and echocardiographically determined left ventricular mass in healthy subjects. Am J Cardiol 1991; 67: 425-427.

11. Brembilla-Perrot B, Claudon O, Houriez P, Beurrier D, Suty-Selton $\mathrm{Ch}$. Absence of change of signal-averaged electrocardiogram identifies patients with ventricular arrhythmias who are non-responders to amiodarone. Int J Cardiol 2002; 83: 47-55. 